\title{
On the Simultaneity Problem in the Aid and Growth Debate*
}

\author{
Markus Brückner \\ Universitat Pompeu Fabra
}

August 2010

\begin{abstract}
This paper shows that foreign aid has a significant positive average effect on real per capita GPD growth if, and only if, the quantitatively large negative reverse causal effect of per capita GDP growth on foreign aid is adjusted for in the growth regression. Instrumental variables estimates yield that a 1 percentage point increase in GDP per capita growth decreased foreign aid by over 4 percent. Adjusting for this quantitatively large, negative reverse causal effect of economic growth on foreign aid yields that a 1 percent increase in foreign aid increased real per capita GDP growth by around 0.1 percentage points.
\end{abstract}

Keywords: Aid Allocation, Aid Effectiveness, Economic Growth, Simultaneity.

JEL: 01, 02, 04.

*Universitat Pompeu Fabra, Department of Economics, Ramon Trias Fargas 25-27, 08005 Barcelona, Spain. E-mail: markus.bruckner@upf.edu; telephone: 0034 681039957; fax: 0034 34935422533. I thank Fabio Canova, Francesco Caselli, Antonio Ciccone and Marta ReynalQuerol for helpful comments and suggestions. The paper has also benefited from discussion at the Applied Economics and Econometrics Seminar at the University of Mannheim. 


\section{Introduction}

Does foreign aid have a positive, causal effect on economic growth? I show that the answer to this important policy question is yes if, and only if, one takes into account that economic growth itself has a quantitatively large, negative effect on foreign aid. The aid effectiveness literature is well aware of this endogeneity problem. ${ }^{1}$ However, despite standard macroeconomic theory predicting a positive effect of foreign aid on economic growth if part of the foreign aid is used for investment, the status quo in the aid effectiveness literature is that foreign aid does not have a significant positive average effect on economic growth. I show that indeed one may arrive at this conclusion if the negative reverse causal effect of per capita GDP growth on foreign aid is not accounted for in the growth regression. Once the negative reverse causal effect of economic growth on foreign aid is accounted for, estimates of the effect of foreign aid on economic growth are positive, statistically significant, and economically meaningful.

My estimation strategy to identify the causal effect of foreign aid on economic growth is based on a two-step procedure. The two-step procedure is closely related to the approach taken in the empirical macro literature to identify the causal effects of fiscal policy (see, in particular, Blanchard and Perotti, 2002). In the first step, I estimate the response of foreign aid to economic growth, using rainfall and international commodity price shocks as instrumental variables to generate exogenous variation in real per capita GDP growth for a panel of 47 LDCs during the period 1960-2000. In the second step, after the causal response of foreign aid to real per capita GDP growth is quantified by the instrumental variables estimates, I use the residual variation in foreign aid that is not driven by GDP per capita growth as an instrument to estimate by two-stage least squares the effect that foreign aid has on per capita GDP growth. This twostep estimation strategy enables to: (i) obtain an understanding of how foreign aid responds to per capita GDP growth at the macroeconomic level (hence, providing useful information on the severity of the endogeneity bias if one fails to adequately deal in the growth regression with the endogenous response of foreign aid to economic growth); and (ii) compute an estimate of the effect that foreign aid has on economic growth that is adjusted for the reverse causal effect that growth has on aid.

My first main finding is that increases in real per capita GDP growth of aid recipient countries are associated with a statistically significant and quantitatively large reduction in foreign aid. An instrumental variables estimate yields that a 1 percentage point increase in the real per capita GDP growth rate is associated with a significant decrease in foreign aid by over 4 percent. This result is consistent with the stylized cross-country fact that as countries grow

\footnotetext{
${ }^{1}$ See for example Burnside and Dollar (2000), Hansen and Tarp (2001), Dalgaard et al. (2004), Easterly et al. (2004), Roodman (2007), Bourguignon and Sundberg (2007), or Rajan and Subramanian (2008). One of the main problems that this literature is struggling with, is finding an instrumental variable for foreign aid that plausibly satisfies the exclusion restriction in the growth equation (see Rajan and Subramanian, 2008, for a discussion and overview). Papers that have studied aid allocation criteria include, among many others, Trumbull and Wall (1994), Alesina and Dollar (2000), and Alesina and Weder (2002).
} 
richer they rely less on foreign aid. It is also consistent with donor countries acting as Good Samaritans: when the economy of the aid recipient country is booming the Good Samaritan reduces aid, while in times of severe economic difficulties aid is increased.

An important implication of this first main finding is that research on the effect of foreign aid on economic growth is complicated by a quantitatively large, negative reverse causal effect of economic growth on foreign aid. The large, negative causal effect of economic growth on foreign aid implies that the cards in empirical research on aid effectiveness are stacked against finding in the data a significant positive average effect of foreign aid on economic growth.

I show that once the negative reverse causal effect of per capita GDP growth on foreign aid is adjusted for in the growth regression, that foreign aid did indeed have a significant positive average effect on real per capita GDP growth. My panel fixed effects estimates yield that a 1 percent increase in foreign aid is associated with a significant within-country increase in GDP per capita growth of around 0.1 percentage points. These instrumental variables estimates are consistent with the quantitative predictions of a Solow-Swan growth model where a part of foreign aid finances domestic investment. I also show that estimating the effect that foreign aid has on GDP per capita growth without taking into account that there is a large, negative reverse causal effect of economic growth on foreign aid would lead to the (mistaken) conclusion that foreign aid has no significant positive average effect on real per capita GDP growth.

The remainder of the paper is organized as follows. Section 2 explains the estimation strategy. Section 3 describes the data. Section 4 presents the main results. Section 5 presents further robustness checks. And Section 6 concludes.

\section{Estimation Strategy}

\subsection{Estimating the Effect that Economic Growth has on Foreign Aid}

Estimating the effect that real per capita GDP growth has on foreign aid requires an exogenous source of variation for real per capita GDP growth. To generate such variation, I use smooth variations in rainfall and international commodity price shocks as instrumental variables. ${ }^{2}$ A key characteristic of the Least Developed Countries (LDCs) that makes this estimation strategy plausible is that these countries are highly dependent on the agricultural and commodity exporting sector. ${ }^{3}$ Hence, variations in rainfall and international commodity

\footnotetext{
${ }^{2}$ Several papers have documented the significant effect of rainfall and international commodity price shocks on economic growth in Sub-Saharan Africa. See for example Deaton (1999), Miguel et al. (2004), or Brückner and Ciccone (2008, 2010). Sub-Saharan African countries constitute about two-thirds of the 49 countries that are classified by the United Nations as the Least Developed Countries (LDCs). The paper covers 47 of the 49 LDCs. The 2 LDCs that are not covered in the paper due to missing GDP data are East-Timor and Myanmar.

${ }^{3}$ See the Data Appendix for further details.
} 
prices can induce substantial variation in real per capita GDP growth vis-a-vis changes in agricultural productivity and the terms of trade. Because rainfall is random and the economic size of each LDC (as measured by the share in world commodity production) is extremely small (so that the country can be effectively treated as being a price taker on the international commodity market) the induced variations in per capita GDP growth will be exogenous to variations in foreign aid and economic growth. ${ }^{4}$

I estimate the effect that real per capita GDP growth has on foreign aid using two-stage least squares:

$$
\Delta \log \left(\operatorname{aid}_{i, t}\right)=a_{i}+b_{t}+c \Delta \log \left(y_{i, t}\right)+e_{i, t}
$$

where $\Delta \log \left(\operatorname{aid}_{i, t}\right)$ is the log-change of foreign aid per capita and $\Delta \log \left(y_{i, t}\right)$ is the log-change of real per capita GDP. ${ }^{5} a_{i}$ are country fixed effects that capture longrun (unobservable) differences across countries that jointly determine changes in foreign aid per capita and per capita GDP growth; $b_{t}$ are year fixed effects that capture global business cycle effects and other global shocks that may be jointly driving foreign aid and per capita GDP growth of the LDCs.

The excluded instruments $\left(Z_{i, t}\right)$ in the two-stage least squares estimation of equation (1) are the log-changes of the international commodity price index, rainfall, and rainfall squared (see Section 3 for a detailed description of how these instruments are constructed). The exclusion restriction states that the instruments should only systematically affect the dependent variable (foreign aid per capita) through their effect on per capita GDP growth. The validity of rainfall and commodity price shocks as excluded instruments in equation (1) will be examined rigorously in Section 4.1.

\subsection{Estimating the Effect that Foreign Aid has on Eco- nomic Growth}

If per capita GDP growth has a significant effect on foreign aid (i.e. in equation $(1) c \neq 0$ ) then OLS estimation of the effect that foreign aid has on economic growth will be biased. Specifically, suppose that the effect of foreign aid on economic growth can be written as:

$$
\Delta \log \left(y_{i, t}\right)=h_{i}+i_{t}+k \Delta \log \left(\operatorname{aid}_{i, t}\right)+m Z_{i, t}+u_{i, t}
$$

then $\operatorname{cov}\left(\Delta \log \left(\operatorname{aid}_{i, t}\right), u_{i, t}\right) \neq 0$, and OLS estimation of $k$ will be upward biased if $c>0$ and downward biased if $c<0$.

\footnotetext{
${ }^{4}$ Conditional of course on country and year fixed effects. See the equation below.

${ }^{5}$ This functional form follows directly Trumball and Wall (1994), who derive the panel fixed effects log-log specification based on a theoretical model where aid decisions of donors are motivated by the well-being of the aid recipient country. I use the log-change of foreign aid rather than the level of foreign aid because the Hadri (2000) LM panel unit root test rejected the null hypothesis that the level of the foreign aid series is stationary at the $1 \%$ level; the Im, Pesaran, and Shin (2003) test could not reject the hypothesis that the level of foreign aid follows a unit root, but rejected at the $1 \%$ level that the first-difference of the foreign aid series has a unit root.
} 
This endogeneity bias, that is due to $c \neq 0$ in equation (1) can be evaded however by (i) constructing an adjusted foreign aid series where the response of foreign aid to per capita GDP growth is partialled out; i.e.:

$$
\Delta \log \left(\operatorname{aid}_{i, t}\right)^{*}=\Delta \log \left(\operatorname{aid}_{i, t}\right)-c \Delta \log \left(y_{i, t}\right)
$$

and (ii) using this endogeneity adjusted aid series as an instrument for the original aid series in equation (2). By construction, the IV estimator that uses the endogeneity adjusted aid series $\Delta \log \left(a i d_{i, t}\right)^{*}$ as an instrument for $\Delta \log \left(a_{i d_{i, t}}\right)$ does not suffer from the simultaneity bias. Moreover, beyond taking care of the simultaneity bias, that is associated with the least squares estimation of equation (2), the IV estimator will provide a consistent estimate of the parameter $k$ under the assumption (exclusion restriction) that the error in equation (1) is uncorrelated with the error in equation (2). If there are omitted variables that are part of both, equations (1) and (2) the zero-covariance assumption will be violated and the IV estimator will not solve the omitted variables problem. However, the IV estimator will still solve the simultaneity problem. The Technical Appendix provides a formal proof for why an IV estimator that uses the residual variation of foreign aid which is not driven by economic growth does not suffer from the simultaneity bias. The appendix also derives the omitted variables bias of the least squares and IV estimator which arises when the zero-covariance restriction is violated.

Note that the estimation strategy requires that the parameter $c$ in equation (1) is estimated consistently. Because of the simultaneous nature of the two equations, OLS can not provide a consistent estimate of the parameter $\mathrm{c}$ in equation (1) if $k \neq 0$ in equation (2). Moreover, because measurement error is a real concern in national accounts statistics of developing countries (e.g. Heston, 1994; Deaton, 2005) the OLS estimate of the parameter $c$ in equation (1) will likely be attenuated towards zero. Hence, the need for instrumental variables estimation of equation (1).

An issue arising with the estimation strategy in equation (2) is that the adjusted aid series $\left(a i d_{i, t}\right)^{*}$ is a generated regressor. Typically, the presence of a generated regressor leads to standard errors on the slope coefficients that are incorrect for purposes of hypothesis testing. ${ }^{6}$ However, there is a special case where the standard error on the slope coefficient of a generated regressor is correct: namely, for testing the hypothesis that the slope coefficient is equal to zero (see, for example, Wooldridge, 2002, p. 141). In the aid literature the debate has focused on the question of whether the effect of foreign aid on economic growth is significantly different from zero. Hence, the special case where the standard error on the slope coefficient of a generated regressor is correct (i.e. the case for testing the hypothesis of a zero slope coefficient on foreign aid) is the relevant one for this paper's empirical analysis.

\footnotetext{
${ }^{6}$ Consistency of the estimator is of course not affected by the use of a generated regressor.
} 


\section{Data}

Rainfall Data. I obtain data on annual rainfall for each of the 47 LDCs during the period 1960-2000 from the Climate Research Unit (CRU) and the Tyndall Centre for Climate Change Research (TYN) of the University of East Anglia. Specifically, I use the TYN CY 1.1 version that has been developed by Mitchell et al. (2003) and approved by the Intergovernmental Panel on Climate Change (IPCC). The CRU/TYN rainfall data come at a high resolution $\left(0.5^{\circ} \times 0.5^{\circ}\right.$ latitude-longitude grid) and each rainfall observation in a given grid is constructed by interpolation of rainfall observed by all stations operating in that grid. Rainfall data are then aggregated to the country level by assigning grids to the geographic borders of countries and weighting the observation in each grid by surface area, using the cosine of the latitude (see Mitchell et al., 2003 for more details).

International Commodity Price Shocks. The country-specific international commodity export price index $C o m P I_{i, t}$ that captures shocks to the international prices of exported commodities is constructed as:

$$
\operatorname{ComPI} I_{i, t}=\prod_{c \in C} \operatorname{ComPrice}_{c, t}^{\theta_{c, i}}
$$

where ComPrice Cot, $_{\text {is }}$ the international price of commodity $c$ in year $t$, and $\theta_{c, i}$ is the average (time-invariant) value of exports of commodity $c$ in the GDP of country $i$. Annual international commodity price data are for the 19602000 period from UNCTAD Commodity Statistics, and data on the value of commodity exports are from the NBER-United Nations Trade Database. ${ }^{7}$

GDP and Foreign Aid Data. The real per capita GDP data are from the Penn World Tables (PWT), version 6.2 (Heston et al., 2006). Data on net official development aid are from the World Development Indicators (2009). ${ }^{8}$

\section{Main Results}

\subsection{Estimates of the Effect of Economic Growth on Foreign Aid}

Table 1 presents the baseline two-stage least squares estimates of the effect that real per capita GDP growth has on foreign aid. Column (1) shows the first-stage

\footnotetext{
${ }^{7}$ The commodities included in the index are: aluminum, beef, coffee, cocoa, copper, cotton, gold, iron, maize, oil, rice, rubber, sugar, tea, tobacco, wheat, and wood. In case there were multiple prices listed for the same commodity a simple average of all the relevant prices is used.

${ }^{8} \mathrm{I}$ use net official development aid, defined as grants and concessional loans net of repayments, because this measure captures best the actual transfers to countries (see for example Easterly, 2003, p. 29). I have chosen to focus on total official development aid, rather than more specific measures of aid, because if aid is fungible, as argued for instance in Devarajan and Swaroop (1998), then conceptually it makes little sense to distinguish between different kinds of foreign aid (see also Rajan and Subramanian, 2008).
} 
estimates that link international commodity price shocks and rainfall $\left(Z_{i, t}\right)$ to real per capita GDP growth $\Delta \log \left(y_{i, t}\right)$. All three instruments are individually significant at least at the $1 \%$ level and yield a first-stage F-statistic of about 9.3. Increases in the international prices of exported commodities and improved rainfall conditions are associated with a significant increase in the real per capita GDP growth of the LDCs. The negative quadratic term on the rainfall variable captures that at some stage too much rainfall may be counterproductive for agricultural productivity and hence for GDP per capita growth.

That the instruments $Z_{i, t}$ have also a significant reduced-form effect on foreign aid $\Delta \log \left(\operatorname{aid}_{i, t}\right)$ is shown in column (2). Increases in the international prices for exported commodities and improved rainfall conditions are associated with a significant decrease in foreign aid. Because the regression controls for year fixed effects, the reduced-form estimates are not driven by changes in economic conditions of OECD countries that may in turn systematically affect movements of international commodity prices. Moreover, the country fixed effects take into account that some LDCs are more dependent on the agricultural and commodity exporting sector than others, and that aid flows may be determined by deep historical factors, such as for example colonial ties to a specific European country.

For comparison purposes with the second-stage estimates that are presented in columns (4)-(8), column (3) shows the least squares estimates of the effect that real per capita GDP growth has on foreign aid. The least squares estimate is negative and statistically significant at the $5 \%$ level. However, if foreign aid has a significant effect on GDP per capita growth this point estimate can not be taken as reflecting the causal effect that per capita GDP growth has on foreign aid. In fact, if foreign aid has a significant positive effect on GDP per capita growth, the least squares estimate of the effect that GDP per capita growth has on foreign aid will be upward biased.

Column (4) therefore presents the two-stage least squares estimate that uses international commodity price shocks and rainfall as excluded instruments. The second-stage point estimate on real GDP per capita growth from the two-stage least squares regression is statistically significant at the $5 \%$ level and in absolute size much larger than the corresponding least squares estimate in column (3). The larger absolute size of the coefficient from the two-stage least squares regression could be due to a number of factors. First, if foreign aid has a positive effect on GDP per capita growth the least squares estimate will be upward biased. Second, measurement error in per capita GDP growth is a real issue for the LDCs (see for example, Heston, 1994; or Deaton, 2005). To the extent that this measurement error is classical it will attenuate the slope coefficient in the least squares regression towards zero but not the slope coefficient in the twostage least squares regression. The Hausman test rejects that the least squares estimate is equal to the two-stage least squares estimate at the $10 \%$ level (pvalue 0.067 ), thus pointing to a significant difference between the least squares and instrumental variables estimate.

Quantitatively, the two-stage least squares estimate in column (4) implies that a 1 percentage point increase in real per capita GDP growth is associated 
with an average reduction in foreign aid by over 4 percent. For this two-stage least squares estimate to reflect the causal effect that per capita GDP growth has on foreign aid, it is necessary that the instruments fulfill the exclusion restriction. That is, rainfall and international commodity price shocks should have no systematic effects on foreign aid other than through GDP per capita growth.

The p-value of the Hansen J-test on the overidentifying restrictions reported in column (4) is 0.82 . Hence, the Hansen J-test does not reject that the instruments are uncorrelated with the second-stage error. To show also more intuitively that beyond per capita GDP growth there are no systematically large direct effects of international commodity price shocks and rainfall on foreign aid I report in columns (5)-(7) two-stage least squares estimates when instruments are added to the right-hand side of the second-stage equation. As can be seen, the size of the coefficient on the international commodity price index conditional on real per capita GDP growth (columns (5) and (6)) is less than one-third of the size of the coefficient that is obtained in the reduced-form regression (column (2)). Statistically, the coefficient is also not significant at any conventional confidence level. The coefficient on rainfall on the other hand flips sign and is also statistically insignificant. These regressions that directly estimate the effect that the instruments have on foreign aid conditional on per capita GDP growth therefore resonate the result of the Hansen J-test that did not reject the validity of rainfall and international commodity price shocks as instrumental variables for real per capita GDP growth in the aid equation. Column (8) shows that the second-stage (and first-stage) relationship continues to hold when excluding all those country-years where LDCs experienced a drought year, which could be associated with an atypical influx of foreign aid. ${ }^{9}$

An issue that has received substantial attention in particular in the aid literature is the robustness of results to outliers and the sample size. ${ }^{10}$ To show that within the LDC sample results are robust to the selection of a specific sub-sample and the exclusion of observations that may be deemed as potential outliers Table 2 presents a variety of robustness checks. In column (1) only those country-year observations are used for the two-stage least squares estimation that produce a balanced panel for the 1960-2000 period. The point estimate on the second-stage coefficient is in this case -5.47 and is statistically significant at the $1 \%$ level. In column (2) the balanced sample is maintained, but all those observations are excluded which are deemed as outliers by the Hadi (1992) procedure. ${ }^{11}$ Excluding these outliers barely changes the second-stage point estimate, but it does make the first-stage fit a bit more precise. In columns (3)-(5) the sample period is elevated to cover the 1970-2000 period only. The

\footnotetext{
${ }^{9}$ Drought years are identified using the publicly available data on natural disasters that are provided by the Universite Catholic de Louvain's Emergency Disaster database (EM-DAT, 2009).

${ }^{10}$ See for example Easterly et al. (2004) or Roodman (2007).

${ }^{11}$ The Hadi (1992) procedure for detecting outliers has been popularly used in the aid literature. See for example Easterly et al. (2004) or Roodman (2007). The cut-off significance level chosen for the Hadi procedure is $5 \%$.
} 
motivation for focusing on the 1970-2000 period is that some of the LDCs during the 60 s were still under colonial influence of the European countries. Column (3) presents the unbalanced panel estimates for the 1970-2000 period, while column (4) uses only those 39 LDCs that yield a balanced panel for the 19702000 period. Column (5) excludes further potential outliers based on the Hadi procedure. The main result is that per capita GDP growth continues to have a significant negative effect on foreign aid in all these regressions. Point estimates range between -4.19 and -6.07 and their $95 \%$ confidence intervals span the point estimate obtained in column (4) of Table $1 .{ }^{12}$

\subsection{Estimates of the Effect that Foreign Aid has on Economic Growth}

The results of the previous section showed that foreign aid is highly endogenous to the per capita GDP growth of the aid recipient countries. Specifically, the instrumental variables estimates yielded that foreign aid decreased substantially during times when per capita GDP growth of aid recipient countries increased. Hence, an OLS estimate of the effect that foreign aid has on per capita GDP growth will suffer from downward bias due to the reverse negative effect that per capita GDP growth has on foreign aid.

Panel A of Table 3 shows estimates of the effect of foreign aid on per capita GDP growth when adjusting for the large negative effect that GDP per capita growth has on foreign aid (for an explanation of how this is done see Section 2.2). ${ }^{13}$ Panel B reports for comparison purposes the OLS estimates. All regressions continue to control for country and year fixed effects.

The main message of the estimates in Panel A of Table 3 is that the effect of foreign aid on real per capita GDP growth is positive and significantly different from zero at over $99 \%$ confidence when the negative reverse causal effect of GDP per capita growth on foreign aid is adjusted for. On the other hand, in Panel $\mathrm{B}$ of Table 3 the OLS estimates, that suffer from the negative reverse causal effect are either statistically insignificant or significantly negative. These results hold across a variety of different sub-sample specifications and are robust to the exclusion of observations that are deemed as potential outliers by the Hadi procedure. Specifically, the instrumental variables estimates in Panel A of Table

\footnotetext{
${ }^{12}$ An additional criterion that is important for instrumental variables estimation to yield consistent second-stage estimates is the first-stage relevance of the instruments. The firststage F-statistic in Tables 1 and 2 is between 7.8 and 15.8. According to the tabulations in Stock and Yogo (2005), the maximal IV relative bias (maximal size distortion) is therefore less than $5 \%$ to $20 \%$ ( $15 \%$ to $25 \%$ ). The p-values reported in square brackets below the 2SLS estimates in Tables 1 and 2 are based on the Anderson-Rubin test of statistical significance, and a key property of this test statistic is robustness to weak instruments (see for example Andrews and Stock, 2005). In Appendix Table 1 I show that using weak IV robust estimators yields second-stage estimates that are very similar, both quantitatively and statistically, to the two-stage least squares estimates reported in Tables 1 and 2.

${ }^{13}$ The adjustment is done using the corresponding point estimates of the effect that economic growth has on aid from Tables 1 and 2, thus matching the sample size in each column of Table 3.
} 
3 yield that a 1 percent increase in foreign aid is associated with a significant increase in real per capita GDP growth by around 0.1 to 0.2 percentage points. ${ }^{14}$

Table 4 shows that there continues to be a significant positive average effect of foreign aid on economic growth when controlling for within-country changes in political institutions. Changes in political institutions could have a direct and independent effect on foreign aid beyond economic growth if due to political reasons donors prefer to give foreign aid to more democratic countries. ${ }^{15}$ For within-country changes in political institutions to be an omitted variable in the growth equation it would have to be the case however that at the annual level a change in political institutions has an immediate effect on economic growth. Panel A of Table 4 shows that this is not the case. The coefficient on the Polity2 score that captures political institutions is statistically insignificant and quantitatively small. The average marginal effect of foreign aid on economic growth remains on the other hand positive and highly statistically significant. ${ }^{16}$

\section{$5 \quad$ Further Issues}

\subsection{Cross-Country Parameter Heterogeneity}

The log-log difference specification (see equation (2)) implies that, cross-country differences in the effect that a change in the level of foreign aid has on the level of GDP per capita are differenced out. However, it is likely that also the elasticity effect of foreign aid on GDP per capita growth differs across countries (as would for example be suggested by a standard Solow-Swan growth model; see Section 5.2 below). To check whether parameter heterogeneity leads to a bias in the estimated average effect, I use the mean-group estimator developed by Pesaran and Smith (1995) that computes estimates country-by-country and then takes a linear average of the obtained coefficients. Figure 1 plots the kernel density function of the country-specific slope estimates that are obtained from using as an instrumental variable the residual variation in foreign aid that is not driven by economic growth. ${ }^{17}$ The mean value of the country-specific slope estimates is 0.11 , and thus matches closely the estimate of the average marginal effect

\footnotetext{
${ }^{14}$ Appendix Table 2 shows that similar results are obtained when applying the instrumental variables strategy to the publicly available datasets of Burnside and Dollar (2000), Easterly et al. (2004), or Roodman (2007).

${ }^{15}$ See, for example, Trumball and Wall (1994), or Alesina and Dollar (2000).

${ }^{16}$ Panel B of Table 4 shows that increases in countries' Polity2 scores are associated with significant increases in foreign aid. While there is no significant contemporaneous effect of economic growth on the Polity2 score when using rainfall and the international commodity price index as instruments for GDP growth (results not shown), the correlation in Panel B is unlikely to reflect the true causal effect that foreign aid has on economic growth. Barro and Lee (2005) and Djankov et al. (2008), for example, provide evidence that foreign aid can have adverse effects on countries' political institutions. In this case, the estimate in Panel B of Table 4 reflects a lower bound on the true causal effect that political change has on foreign aid.

${ }^{17}$ The reported estimates in Figure 1 are based on the largest possible sample (47 countries during 1960-2000).
} 
reported in column (1) of Table 3 from the homogenous panel fixed effects model.

Beyond providing an important robustness check on the average marginal effect obtained from the homogenous panel fixed effects model, the countryspecific slope estimates provide useful information on the extent to which the effect of foreign aid on economic growth varies across countries. The interquartile range of the country-specific slope estimates is $[0.05,0.15]$, with a sample minimum (maximum) of $-0.02(0.35)$. Hence, there is quite a bit of variation in the marginal effect that foreign aid has on economic growth across countries, which raises the interesting policy question of what determines this cross-country variation.

One explanation for the cross-country variation in the marginal effect of foreign aid on economic growth are cross-country differences in economic policies. Burnside and Dollar (2000) argued that the marginal effect of foreign aid on economic growth is particularly high in countries where policy-induced distortions to economic activity are relatively small because in these countries aid is more likely to be invested. ${ }^{18}$ Figure 2 examines this claim empirically by plotting the country-specific slope estimates against the Burnside and Dollar (2000) policy index that captures cross-country differences in trade policy, inflation, and budget balance. The scatter plot shows a positive relationship between the country-specific slope estimates and the (period-average) BD policy index. Using the bootstrap to take into account the relatively small number of observations, a bivariate regression yields a coefficient on the BD policy index of 0.04 that has a t-value of 1.86. Hence, this is supportive evidence for the Burnside and Dollar claim that foreign aid is particularly effective in stimulating economic growth in countries with good macroeconomic policies.

Dalgaard et al. (2004) found that aid is significantly less effective in the tropics. As noted by Rajan and Subramanian (2008), there is little theoretical reason for why one would expect a systematically smaller effect of foreign aid on economic growth in countries which are located in the tropics. Figure 3 shows that regressing the country-specific slope estimates on the share of tropical terrain yields a negative, but statistically insignificant relationship.

Another argument for cross-country heterogeneity in the marginal effect of foreign aid on economic growth, that has been popular in both academic and policy circles, are financing constraints (see e.g. Sachs, 2005). Domestic and, in particular, rural financial markets are often ill-functioning (or simply nonexistant) in many of the LDCs so that high return projects go unrealized because (rural) investors fail to obtain finance for their projects. An aid inflow may have a high return if it successfully targets high return projects and eases financing constraints in the (rural) financial markets. Figure 4, Panels A-C explore the role of such financing constraints by plotting the country-specific slope estimates against various indicators proxying the severity of financial market imperfections. Panel A plots the relationship between the country-specific slope estimates and the World Bank credit information index that captures the avail-

${ }^{18}$ For a critique, see Easterly et al. (2004). 
ability of credit information from either a public registry or a private bureau to facilitate lending decisions. Panel B plots the relationship between the countryspecific slope estimates and the percentage share of individuals and firms listed in a public or private credit registry with current information on repayment history, unpaid debts, or credit outstanding. And, to capture that credit market imperfections are often most severe in rural areas of developing countries Panel $\mathrm{C}$ plots the relationship between the country-specific slope estimates and the percentage share of the population living in rural regions. The main result is that the marginal effect of foreign aid on economic growth is significantly increasing in these proxies for cross-country differences in the severity of financing constraints. Hence, the common argument in favor of foreign aid - the financing problem - finds support in the data.

A strand of the aid effectiveness literature has argued that there exists a political economy resource curse of foreign aid on economic growth: in countries with multiple powerful groups aid inflows may lead to costly rent-seeking activity (e.g. Svensson, 2000; Reinikka and Svensson, 2004). Figure 5, Panels A and B explore this channel by plotting the relationship between the country-specific slope estimates and two measures that capture countries' ethnic fragmentation. Panel A plots the relationship using an index of ethnic fractionalization and Panel B plots the relationship using an index of ethnic polarization. ${ }^{19}$ Both figures show a downward sloping relationship. Statistically the relationship is however only significant at conventional confidence levels for the measure of ethnic fractionalization, which may suggest that aid inflows can be a curse primarily due to the common pool problem, rather than because they directly increase the likelihood of civil conflict. ${ }^{20}$

\subsection{Comparison of IV Estimates to the Predicted Effect from a Solow-Swan Growth Model}

A useful way to check whether the instrumental variables estimates of the average marginal effect are plausible not only in sign but also in size is to draw on the first-order approximation of the effect that a change in the investment rate has on the output growth rate in a simple but standard Solow-Swan growth model. The first-order approximation yields that a 1 percent increase in the investment rate increases the output growth rate by $\beta \frac{\alpha}{1-\alpha}$ percentage points, where $\beta$ is the convergence rate and $\alpha$ the capital-output elasticity. ${ }^{21}$ If part of the foreign aid is used to finance domestic investment, the predicted growth rate effect (in percentage points) of a 1 percent increase in the share of aid in GDP is

\footnotetext{
${ }^{19}$ The fractionalization index increases with the number of groups, while the polarization index is maximized when there are two groups which are of equal size. Both indices are between 0 and 1, with larger values denoting more fractionalization (polarization). For a discussion of conceptual differences between polarization and fractionalization indices with an application to the conflict literature, see Montalvo and Reynal-Querol (2005).

${ }^{20}$ In fact, recent research by De Ree and Nillesen (2009) shows that an increase in foreign aid is associated with a significant decrease in the likelihood of civil conflict.

${ }^{21}$ See for example Barro and Sala-i-Martin (2003).
} 
$\beta \frac{\alpha}{1-\alpha}$ times the marginal elasticity effect that foreign aid has on investment. ${ }^{22}$ Table 5 shows that on average this marginal elasticity effect of foreign aid on investment is around $0.15-0.3$ percent.

To make the instrumental variables estimates comparable therefore to the predictions of the Solow-Swan growth model, and in order to obtain an estimate of the convergence rate $\beta$, Table 6 shows that there continues to be a positive and statistically significant effect of foreign aid on the growth rate of GDP per capita when controlling for convergence effects in the level of GDP per capita and using instead of the log of foreign aid the log of the share of foreign aid in GDP. The system-GMM estimation (Blundell and Bond, 1998) for these dynamic regressions, where the foreign aid share is instrumented by the variation in the aid to GDP ratio that is not driven by GDP per capita growth, yields estimates on the $\log$ of the aid to GDP ratio that range between 0.05 to 0.07 for the 1960-2000 period and between 0.03 to 0.06 for the 1970-2000 period. Statistically, these estimates are significant at the 5 percent level at least. The average annual convergence rate in the sample is estimated to be around 5 to 10 percent per annum.

With these estimates in hand, it is now possible to compare the instrumental variables estimates of the average effect that foreign aid has on economic growth to the quantitative prediction from the Solow-Swan growth model. A typical value used in the empirical growth literature for $\alpha$, that is reasonable for a Solow-Swan growth model with investment in both, physical and human capital, is $2 / 3$ (see e.g. Durlauf et al., 2005). ${ }^{23}$ Hence, the predicted average effect of a 1 percent change in the aid to GDP ratio on the output growth rate is around 0.02 to 0.06 percentage points. This is in line with the instrumental variables estimates reported in Table 6 , which range between 0.03 to 0.07 .

\footnotetext{
${ }^{22}$ Arellano et al. (2008) show in a DSGE model, where consumers are modelled to perfectly smooth consumption over time, that whether an aid inflow increases investment depends on the persistence of the aid shock. A fully permanent aid shock increases consumption, with little effect on investment - a result that follows from the Permanent Income Hypothesis. It is questionable however whether the Permanent Income Hypothesis is a good approximation of consumption choices in the LDCs. Empirically there exists evidence that for the LDCs the Permanent Income Hypothesis is not a good approximation, mainly because of financing constraints (see, for example, Deaton, 1992).

${ }^{23}$ Note that in the Solow-Swan growth model there exists a tight relationship between the convergence rate $\beta$ and the output-capital elasticity $\alpha$. In particular, it holds that $\beta=$ $(1-\alpha)(n+g+d)$, where $n$ and $g$ are the population and TFP growth rates respectively, and $d$ is the depreciation rate (e.g. Barro and Sala-i-Martin, 2003). The average sample population growth rate is about 2.5 percent and a reasonable value for annual TFP growth is about 1 to 2 percent. An $\alpha$ of $2 / 3$ and an estimated convergence rate of 5 to 10 percent would therefore require a depreciation rate of the capital stock of between 10 to 25 percent per annum. For the LDCs, where weather conditions are often extreme, this may not be unreasonable. Bu (2006), for example, presents firm data evidence for Ghana, Ivory Coast, Kenya, and Zimbabwe with average depreciation rates on fixed assets (resp. machinery and equipment) that range between 10 to 20 percent (resp. 15 to 40 percent).
} 


\subsection{Level Effects vs. Growth Effects}

The Solow-Swan growth model predicts that a permanent increase in foreign aid affects GDP per capita growth along the transition to the new steady-state. However, due to the assumption that there are decreasing returns to scale in capital the Solow-Swan growth model predicts that an increase in foreign aid has a level effect but not a long-run growth effect. The empirical results so far are consistent with both a level effect and a growth effect. This is because the first-difference specification that relates the log-change in GDP per capita to the log-change in foreign aid has an analogous level form representation where the log of GDP per capita is related to the log of foreign aid.

To examine whether beyond a level effect an increase in foreign aid has also an effect on the long-run GDP per capita growth rate, I include as an additional right-hand-side regressor in the growth equation the log of the level of foreign aid. This approach follows the empirical growth literature that has tested for long-run growth effects of investment. ${ }^{24}$ In the growth equation, the estimated coefficient on the level of foreign aid reflects the effect that foreign aid has on the long-run GDP per capita growth rate while the estimated coefficient on the log-change of foreign aid reflects the effect that foreign aid has on the level of GDP per capita.

Table 7 reports the estimates for the largest possible sample of 47 countries during the 1960-2000 period. The main result is that the estimated coefficient on the level of foreign aid is statistically insignificant and quantitatively small. On the other hand, the estimated coefficient on the log-change of foreign aid is positive, highly statistically significant, and quantitatively large. Table 7 therefore shows that a permanent increase in foreign aid has a significant positive effect on the level of GDP per capita but an insignificant effect on the long-run GDP per capita growth rate. This result holds for both the static and the dynamic panel data model (columns (1) and (2)). And, it also holds in a distributed lag model where additional lags of foreign aid are included on the right-hand side of the estimating equation (columns (3)-(5)). In particular, the distributed lag estimates (columns (3)-(5)) show that foreign aid has a positive and statistically significant effect on GDP per capita growth on impact, and that the lagged effects are quantitatively smaller in size. The sum of the coefficients on the contemporaneous and lagged log-changes of foreign aid is positive and significantly different from zero at the 1 percent level. Hence, a permanent increase in foreign aid has a significant positive long-run effect on the level of GDP per capita. This result is consistent with the neoclassical Solow-Swan growth model where part of the foreign aid is used to finance domestic investment.

\section{Conclusion}

This paper showed as a first main result that increases in per capita GDP growth of aid recipient countries are associated with a significant decrease in

\footnotetext{
${ }^{24}$ See for example Bond et al. (2010) and the references cited therein.
} 
foreign aid. Specifically, the instrumental variables estimates yielded that a 1 percentage point increase in per capita GDP growth reduced foreign aid by more than 4 percent on average. This finding is consistent with the stylized cross-country fact that as countries grow richer they rely less on foreign aid. It is also consistent with donor countries acting as Good Samaritans.

The paper's finding of a quantitatively large, negative effect of economic growth on foreign aid bears an important implication for empirical research on aid effectiveness: OLS estimates which serve as a natural benchmark of comparison to are biased against finding a significant positive average effect of foreign aid on economic growth. Hence, insignificant estimates of the effect of foreign aid on economic growth should be viewed with skepticism - they may just be a consequence of an inadequately addressed negative and quantitatively large simultaneity bias.

As a second main finding, the paper showed that after the large, negative response of foreign aid to per capita GDP growth is accounted for that foreign aid did indeed have a statistically significant positive effect on per capita GDP growth. This finding contrasts to recent empirical papers that have failed to find a significant positive average effect of foreign aid on economic growth. Because there is a strong tendency at the macroeconomic level for foreign aid to decrease as per capita GDP growth of aid recipient countries increases, the cards are stacked in empirical research against finding a significant positive average effect of foreign aid on economic growth. Hence, if the reverse causality running from higher per capita GDP to less foreign aid is not properly addressed, the researcher may fail to find a significant positive average effect of foreign aid on economic growth and possibly conclude that foreign aid does not have a systematic positive average effect on per capita GDP growth. 


\section{$7 \quad$ References}

Alesina, A. and D. Dollar (2000). "Who Gives Foreign Aid to Whom and Why?" Journal of Economic Growth 5: 33-63.

Alesina, A. and B. Weder (2002). "Do Corrupt Governments Receive Less Foreign Aid?" American Economic Review 92: 1126-37.

Andrews, D. and J. Stock (2005). "Inference with Weak Instruments." NBER Technical Paper No. 0313.

Arellano, C., A. Bulir, T. Lane, and L. Lipschitz (2008). "The Dynamic Implications of Foreign Aid and Its Variability." Journal of Development Economics 88: 87-102.

Barro, R. and X. Sala-i-Martin (2003). Economic Growth. MIT Press, 2nd edition.

Barro, R. and J. Lee (2005). "IMF Programs: Who is Chosen and What Are the Effects." Journal of Monetary Economics 52: 1245-1269.

Blanchard, O. and R. Perotti (2002). "An Empirical Characterization of the Dynamic Effects of Changes in Government Spending and Taxes on Output." Quarterly Journal of Economics 117: 1329-1368.

Blundell, R. and S. Bond (1998). "Initial Conditions and Moment Restrictions in Dynamic Panel Data Models." Journal of Econometrics 87: 115-143.

Bond, S., A. Leblebicioglu, and F. Schiantarelli (2010). "Capital Accumulation and Growth: A New Look at the Empirical Evidence." Journal of Applied Econometrics, forthcoming.

Bourguignon, F. and M. Sundberg (2007). "Aid Effectiveness - Opening the Black Box." American Economic Review 97: 316-321.

Burnside, C. and D. Dollar (2000). "Aid, Policies, and Growth." American Economic Review 90: 847-868.

Brückner, M. and A. Ciccone (2008). "Rain and the Democratic Window of Opportunity." CEPR Discussion Paper No. 6691.

Brückner, M. and A. Ciccone (2010). "International Commodity Price Shocks, Growth, and the Outbreak of Civil War in Sub-Saharan Africa." Economic Journal 120: 519-534.

Bu, Y. (2006). "Fixed Capital Stock Depreciation in Developing Countries: Some Evidence from Firm Level Data." Journal of Development Studies 42: 881-901.

Dalgaard, C., H. Hansen, and F. Tarp (2004). "On the Empirics of Foreign Aid and Growth." Economic Journal 114: 191-216. 
Djankov, S., J. Montalvo, and M. Reynal-Querol (2008). "The Curse of Aid." Journal of Economic Growth 13: 169-194.

De Ree, J. and E. Nillesen (2009). "Aiding violence or peace? The impact of foreign aid on the risk of civil conflict in sub-Saharan Africa." Journal of Development Economics 88: 301-313.

Deaton, A. (1992). "Household Savings in LDCs: Credit Markets, Insurance, and Welfare." Scandinavian Journal of Economics 94: 253-273.

Deaton, A. (1999). "Commodity Prices and Growth in Africa." Journal of Economic Perspectives 13 (3): 23-40.

Deaton, A. (2005). "Measuring Poverty in a Growing World (Or Measuring Growth in a Poor World)." Review of Economics and Statistics 87 (1):1-19.

Devarajan, S., and V. Swaroop (1998). "The Implications of Foreign Aid Fungibility for Development Assistance." Policy Research Working Paper No. 2022, World Bank.

Durlauf, S., P. Johnson, and J. Temple (2005). "Growth Econometrics." Handbook of Economic Growth (Aghion and Durlauf, eds.), North-Holland, 2005 .

Easterly, W. (2003). "Can Foreign Aid Buy Growth?" Journal of Economic Perspectives 17: 23-48.

Easterly, W., R. Levine, and D. Roodman (2004). "Aid, Policies, and Growth: A Comment." American Economic Review 94: 774-778.

EM-DAT (2009). "EM-DATA: The OFDA/CRED International Disasters Database." Universite Catholique de Louvain, Brussels, Belgium.

Hadi, A. (1992). "Identifying Multiple Outliers in Multivariate Data." Journal of the Royal Statistical Society 54: 761-771.

Hadri, K. (2000). "Testing for Stationarity in Heterogeneous Panel Data." Econometrics Journal 3: 148-161.

Hansen, H. and F. Tarp (2001). "Aid and Growth Regressions." Journal of Development Economics 64: 547-70.

Heston, A. (1994). "A Brief Review of Some Problems in Using National Accounts Data in Level of Output Comparisons and Growth Studies." Journal of Development Economics 44: 29-52.

Heston, A., Summers, R., and B. Aten (2006). Penn World Table Version 6.2. Center for International Comparisons of Production, Income and Prices, University of Pennsylvania, September 2006. 
Im, K., M. Pesaran, and Y. Shin (2003). "Testing for Unit Roots in Heterogeneous Panels." Journal of Econometrics 115: 53-74.

Miguel, E., S. Satyanath, and E. Sergenti (2004). "Economic Shocks and Civil Conflict: An Instrumental Variables Approach." Journal of Political Economy 112 (41): 725-753.

Mitchell, T., Carter, T., Jones, P., Hulme, M., and M. New (2003). "A Comprehensive Set of High-Resolution Grids of Monthly Climate for Europe and the Globe: The Observed Record (1901-2000) and 16 Scenarios (20012100)." Tyndall Centre for Climate Change Research.

Montalvo, Jose and Marta Reynal-Querol (2005). "Ethnic Polarization, Potential Conflict, and Civil War." American Economic Review 95: 796-816.

Pesaran, M. and R. Smith (1995). "Estimating Long-Run Relationships from Dynamic Heterogeneous Panels." Journal of Econometrics 68: 79-113.

Rajan, R. and A. Subramanian (2008). "Aid and Growth: What Does the Cross-Country Evidence Really Show?" Review of Economics and Statistics 90: 643-665.

Reinnika, R. and J. Svensson (2004). "Local capture: evidence from a government transfer program in Uganda." Quarterly Journal of Economics 119: 679-705.

Sachs, J. (2005). The End of Poverty: Economic Possibilities for Our Time. Penguin Press: New York, 2005.

Stock, J. and M. Yogo (2005). "Testing for Weak Instruments in Linear IV Regression." In Identification and Inference for Econometric Models: Essays in Honor of Thomas Rothenberg, ed. D. Andrews and J. Stock, 80-108, Cambridge: Cambridge University Press.

Svensson, J. (2000). "Foreign aid and rent-seeking." Journal of International Economics 51: 437-461.

Trumbull, W. and H. Wall (1994). "Estimating Aid-Allocation Criteria with Panel Data." Economic Journal 104: 876-882.

World Bank (2009). World Development Indicators. Online Database. 


\section{Technical Appendix}

\subsection{Adjustment of the Simultaneity Bias}

This appendix shows formally why an instrumental variables estimator, that uses the variation in foreign aid which is not driven by economic growth as an instrumental variable for foreign aid is immune to the simultaneity bias. For clarity, let us consider the simplest possible simultaneous equation model:

$$
\begin{aligned}
& G D P=\gamma_{1} A i d+u \\
& A i d=\gamma_{2} G D P+e
\end{aligned}
$$

The probability limit of the OLS estimator of $\gamma_{1}$ in equation (5) is:

$$
\gamma_{1}^{O L S}=\gamma_{1}+\frac{\operatorname{cov}(\text { Aid }, u)}{\operatorname{var}(\text { Aid })}
$$

Substituting equation (5) into (6), and rearranging yields the equilibrium condition:

$$
A i d=\frac{1}{1-\gamma_{1} \gamma_{2}}\left(\gamma_{2} u+e\right)
$$

Hence, by substitution of equation (8) into (7) yields

$$
\gamma_{1}^{O L S}=\gamma_{1}+\frac{\gamma_{2}}{1-\gamma_{1} \gamma_{2}} \frac{\operatorname{var}(u)}{\operatorname{var}(\text { Aid })}+\frac{1}{1-\gamma_{1} \gamma_{2}} \frac{\operatorname{cov}(e, u)}{\operatorname{var}(\text { Aid })},
$$

where the second term on the right-hand side of equation (9) captures the simultaneity bias that arises if $\gamma_{2} \neq 0$ in equation (6), and the third term captures the omitted variables bias. ${ }^{25}$

Suppose now that one is able to obtain a consistent estimate of $\gamma_{2}$ in equation (6). ${ }^{26}$ Using this consistent estimate, one can construct an aid series $A i d^{*}$ that is adjusted for the endogenous response (i.e. $\operatorname{Aid}^{*}=\operatorname{Aid}-\gamma_{2} G D P$ ) and use this variable as an instrument for the original aid variable $A i d$ in equation (5). The probability limit of this IV estimator is

$$
\gamma_{1}^{I V}=\frac{\operatorname{cov}\left(A i d^{*}, G D P\right)}{\operatorname{cov}\left(A i d^{*}, A i d\right)}=\gamma_{1}+\frac{\operatorname{cov}\left(A i d^{*}, u\right)}{\operatorname{cov}\left(A i d^{*}, A i d\right)}=\gamma_{1}+\frac{\operatorname{cov}(e, u)}{\operatorname{cov}(e, A i d)} .
$$

Hence, the IV estimator that uses the endogeneity adjusted aid series $A i d^{*}$ as an instrument for Aid does not suffer from the simultaneity bias.

\footnotetext{
${ }^{25}$ To see that the third term in equation (9) captures the omitted variables bias, set $\gamma_{2}=0$. In this case $A i d=u$ and the probability limit of the OLS estimator is simply $\gamma_{1}+\frac{\operatorname{cov}(\operatorname{Aid}, e)}{\operatorname{var}(\operatorname{Aid})}$.

${ }^{26}$ Of course, this can only be done by having a valid instrument for GDP in equation (6). OLS cannot provide in equation (6) a consistent estimate for $\gamma_{2}$ if in equation (5) $\gamma_{1} \neq 0$.
} 


\subsection{Size of the Omitted Variables Bias}

Regarding the size of the omitted variables bias of the IV estimator $\left(O V B^{I V}\right)$ that arises if $\operatorname{cov}(e, u) \neq 0$, note that the second term in equation (10) simplifies to

$$
O V B^{I V}=\left(1-\gamma_{1} \gamma_{2}\right) \frac{\operatorname{cov}(e, u)}{\operatorname{var}(e)+\gamma_{2} \operatorname{cov}(e, u)} .
$$

The third term in equation (9) that captures the omitted variables bias of the least squares estimator $\left(O V B^{I V}\right)$ simplifies to

$$
O V B^{L S}=\left(1-\gamma_{1} \gamma_{2}\right) \frac{\operatorname{cov}(e, u)}{\operatorname{var}(e)+\gamma_{1}^{2} \operatorname{var}(u)+2 \gamma_{2} \operatorname{cov}(e, u)} .
$$

Depending on $\gamma_{1}^{2} \operatorname{var}(u)$ and the sign and size of $\gamma_{2} \operatorname{cov}(e, u)$, the omitted variables bias of the IV estimator may, therefore, be smaller or larger than the omitted variables bias of the least squares estimator. 


\section{Data Appendix}

List of Countries and Summary Statistics

\begin{tabular}{|c|c|c|c|c|c|c|c|}
\hline Country & $\mathrm{Aid} / \mathrm{GDP}$ & Agri/GDP & Export/GDP & Country & $\mathrm{Aid} / \mathrm{GDP}$ & Agri/GDP & Export/GDP \\
\hline Afghanistan & 0.4 & 58 & 18 & Madagascar & 1.8 & 62 & 20 \\
\hline Bangladesh & 0.8 & 73 & 8 & Malawi & 3.4 & 37 & 22 \\
\hline Benin & 2.1 & 19 & 29 & Maldives & 3.1 & 28 & 89 \\
\hline Bhutan & 3.0 & 9 & 26 & Mali & 3.3 & 27 & 20 \\
\hline Burkina Faso & 2.7 & 32 & 10 & Mauritania & 7.3 & 38 & 41 \\
\hline Burundi & 2.3 & 78 & 9 & Mozambique & 2.8 & 62 & 10 \\
\hline Cambodia & 1.1 & 20 & 20 & Nepal & 0.9 & 28 & 13 \\
\hline Cameroon & 0.9 & 19 & 22 & Niger & 2.5 & 26 & 19 \\
\hline Cape Verde & 6.9 & 17 & 19 & Rwanda & 3.0 & 65 & 8 \\
\hline Chad & 2.3 & 38 & 23 & Samoa & 5.5 & 35 & 31 \\
\hline Comoros & 4.3 & 62 & 14 & Sao Tome \&Principe & 15.7 & 42 & 24 \\
\hline Djibouti & 7.2 & 59 & 43 & Senegal & 3.0 & 42 & 26 \\
\hline Congo, Rep. of & 2.2 & 31 & 58 & Sierra Leone & 2.0 & 43 & 19 \\
\hline Eq. Guinea & 4.1 & 12 & 55 & Solomon Islands & 4.9 & 23 & 47 \\
\hline Eritrea & 5.8 & 73 & 15 & Somalia & 4.6 & 70 & 4 \\
\hline Ethiopia & 1.6 & 31 & 11 & Sudan & 1.9 & 50 & 10 \\
\hline Gambia & 4.9 & 59 & 7 & Tanzania & 3.9 & 36 & 17 \\
\hline Guinea & 0.9 & 49 & 26 & Togo & 2.6 & 57 & 33 \\
\hline Guinea-Bissau & 11.0 & 51 & 16 & Uganda & 1.8 & 55 & 11 \\
\hline Haiti & 1.4 & 58 & 19 & Vanuatu & 7.7 & 11 & 46 \\
\hline Kiribati & 13.7 & 47 & 28 & Yemen & 2.2 & 34 & 27 \\
\hline Laos & 2.4 & 7 & 15 & Zambia & 4.1 & 31 & 34 \\
\hline Lesotho & 3.3 & 78 & 24 & Zimbabwe & 0.5 & 32 & 28 \\
\hline Liberia & 7.6 & 27 & 45 & Average & 3.9 & 42 & 24 \\
\hline
\end{tabular}


Table 1: The Effect of Economic Growth on Foreign Aid (Baseline IV Estimates)

\begin{tabular}{|c|c|c|c|c|c|c|c|c|}
\hline & $\Delta \ln (y)$ & & & & $\ln$ (aid) & & & \\
\hline & (1) & (2) & (3) & (4) & (5) & (6) & (7) & (8) \\
\hline & LS & LS & LS & 2SLS & 2 SLS & 2SLS & 2SLS & 2SLS \\
\hline$\Delta \ln (y)$ & & & $\begin{array}{c}-0.37^{* *} \\
(-2.48)\end{array}$ & $\begin{array}{c}-4.47^{* *} \\
{[0.04]}\end{array}$ & $\begin{array}{l}-4.09^{*} \\
{[0.07]}\end{array}$ & $\begin{array}{l}-3.92^{*} \\
{[0.07]}\end{array}$ & $\begin{array}{c}-6.04^{* * *} \\
{[0.01]}\end{array}$ & $\begin{array}{c}-4.73 * * \\
{[0.05]}\end{array}$ \\
\hline$\Delta \ln (\mathrm{ComPI})$ & $\begin{array}{c}0.35^{* * * *} \\
(3.45)\end{array}$ & $\begin{array}{l}-2.12^{* *} \\
(-2.40)\end{array}$ & & & $\begin{array}{c}-0.69 \\
(-0.48)\end{array}$ & $\begin{array}{c}-0.74 \\
(-0.54)\end{array}$ & & \\
\hline$\Delta \ln$ (Rain) & $\begin{array}{c}0.18^{* * * *} \\
(3.09)\end{array}$ & $\begin{array}{l}-0.69^{*} \\
(-1.76)\end{array}$ & & & $\begin{array}{c}0.03 \\
(0.31)\end{array}$ & & $\begin{array}{c}0.37 \\
(0.46)\end{array}$ & \\
\hline$\Delta \ln (\text { Rain })^{2}$ & $\begin{array}{c}-0.01^{* * * * *} \\
(-2.93)\end{array}$ & $\begin{array}{l}0.05^{*} \\
(1.75)\end{array}$ & & & & $\begin{array}{c}0.00 \\
(0.32)\end{array}$ & $\begin{array}{c}-0.02 \\
(-0.42)\end{array}$ & \\
\hline Hansen J, p-value & . & . & . & 0.82 & . & . & . & 0.48 \\
\hline First Stage F-stat & . & . & . & 9.32 & 8.56 & 9.54 & 11.94 & 15.85 \\
\hline Country FE & Yes & Yes & Yes & Yes & Yes & Yes & Yes & Yes \\
\hline Year FE & Yes & Yes & Yes & Yes & Yes & Yes & Yes & Yes \\
\hline Observations & 1550 & 1550 & 1550 & 1550 & 1550 & 1550 & 1550 & 1316 \\
\hline Countries & 47 & 47 & 47 & 47 & 47 & 47 & 47 & 47 \\
\hline
\end{tabular}


Table 2. The Effect of Economic Growth on Foreign Aid (Robustness of IV Estimates to Different Time Periods, Outliers, and Balanced Panel)

\begin{tabular}{|c|c|c|c|c|c|}
\hline \multicolumn{6}{|c|}{$\Delta \ln ($ aid $)$} \\
\hline & (1) & (2) & (3) & (4) & (5) \\
\hline & $\begin{array}{c}1960-2000 \\
\text { Balanced Panel }\end{array}$ & $\begin{array}{l}1960-2000 \\
\text { Balanced Panel \& } \\
\text { Excluding Outliers }\end{array}$ & $\begin{array}{l}1970-2000 \\
\text { All LDCs }\end{array}$ & $\begin{array}{c}1970-2000 \\
\text { Balanced Panel }\end{array}$ & $\begin{array}{l}1970-2000 \\
\text { Balanced Panel \& } \\
\text { Excluding Outliers }\end{array}$ \\
\hline$\Delta \ln (y)$ & $\begin{array}{c}-5.47^{* * * *} \\
{[0.00]}\end{array}$ & $\begin{array}{c}-5.92^{* * * *} \\
{[0.00]}\end{array}$ & $\begin{array}{l}-4.19^{*} \\
{[0.09]}\end{array}$ & $\begin{array}{c}-5.03^{* *} \\
{[0.04]}\end{array}$ & $\begin{array}{c}-6.07^{* * * *} \\
{[0.00]}\end{array}$ \\
\hline Hansen J, p-value & 0.49 & 0.54 & 0.91 & 0.96 & 0.68 \\
\hline First Stage F-stat & 7.76 & 10.08 & 8.14 & 10.08 & 8.60 \\
\hline Country FE & Yes & Yes & Yes & Yes & Yes \\
\hline Year FE & Yes & Yes & Yes & Yes & Yes \\
\hline Observations & 819 & 811 & 1341 & 1170 & 1150 \\
\hline Countries & 21 & 21 & 47 & 39 & 39 \\
\hline
\end{tabular}

Note: The method of estimation is two-stage least squares. The p-values [in square brackets] are based on the Anderson-Rubin test of statistical significance. All test statistics are based on Huber robust standard errors that are clustered at the country level. The instrumental variables are the log. changes in the commodity price index, rainfall, and rainfall squared. "Significantly different from zero at 90 percent confidense, " 95 percent confidence, $* * 99$ persent confidence. 
Table 3: The Effect of Foreign Aid on Economic Growth (Baseline IV Estimates)

\begin{tabular}{|c|c|c|c|c|c|c|}
\hline \multicolumn{7}{|c|}{$\Delta \ln (y)$} \\
\hline & \multicolumn{6}{|c|}{ Panel A: IV-2SLS Estimates } \\
\hline & (1) & (2) & (3) & (4) & (5) & (6) \\
\hline & $\begin{array}{l}1960-2000 \\
\text { All LDCs }\end{array}$ & $\begin{array}{c}1960-2000 \\
\text { Balanced Panel }\end{array}$ & $\begin{array}{l}1960-2000 \\
\text { Balanced Panel \& } \\
\text { Excluding Outliers }\end{array}$ & $\begin{array}{l}1970-2000 \\
\text { All LDCs }\end{array}$ & $\begin{array}{c}1970-2000 \\
\text { Balanced Panel }\end{array}$ & $\begin{array}{c}1970-2000 \\
\text { Balanced Panel \& } \\
\text { Excluding Outliers }\end{array}$ \\
\hline$\Delta \ln ($ aid) & $\begin{array}{c}0.12^{\text {wikne }} \\
(3.36)\end{array}$ & $\begin{array}{c}0.23^{\text {ean }} \\
(4.39)\end{array}$ & $\begin{array}{c}0.23^{\text {*n+m }} \\
(6.26)\end{array}$ & 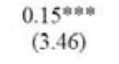 & $\begin{array}{c}0.18^{40.0} \\
(2.72)\end{array}$ & $\begin{array}{c}0.23^{* 3 * * *} \\
(7.18)\end{array}$ \\
\hline First-Stage F-stat & 92.03 & 55.77 & 106.85 & 78.16 & 31.52 & 141.78 \\
\hline Country FE & Yes & Yes & Yes & Yes & Yes & Yes \\
\hline Year FE & Yes & Yes & Yes & Yes & Yes & Yes \\
\hline Observations & 1550 & 819 & 811 & 1341 & 1170 & 1150 \\
\hline \multirow[t]{4}{*}{ Countries } & 47 & 21 & 21 & 47 & 39 & 39 \\
\hline & \multicolumn{6}{|c|}{ Panel B: LS Estimates } \\
\hline & (1) & (2) & (3) & (4) & (5) & (6) \\
\hline & $\begin{array}{l}1960-2000 \\
\text { All LDCs }\end{array}$ & $\begin{array}{c}1960-2000 \\
\text { Balanced Panel }\end{array}$ & $\begin{array}{c}1960-2000 \\
\text { Balanced Panel \& } \\
\text { Excluding Outliers }\end{array}$ & $\begin{array}{l}1970-2000 \\
\text { All LDCs }\end{array}$ & $\begin{array}{c}1970-2000 \\
\text { Balanced Panel }\end{array}$ & $\begin{array}{c}1970-2000 \\
\text { Balanced Panel \& } \\
\text { Excluding Outliers }\end{array}$ \\
\hline$\Delta \ln ($ aid) & $\begin{array}{c}-0.01^{* 4} \\
(-2.25)\end{array}$ & $\begin{array}{c}-0.01 \\
(-0.82)\end{array}$ & $\begin{array}{c}-0.00 \\
(-0.25)\end{array}$ & $\begin{array}{l}-0.01^{*} \\
(-1.95)\end{array}$ & $\begin{array}{c}-0.01^{* *} \\
(-2.47)\end{array}$ & $\begin{array}{c}0.00 \\
(0.02)\end{array}$ \\
\hline Country FE & Yes & Yes & Yes & Yes & Yes & Yes \\
\hline Year FE & Yes & Yes & Yes & Yes & Yes & Yes \\
\hline Observations & 1550 & 819 & 811 & 1341 & 1170 & 1150 \\
\hline Countries & 47 & 21 & 21 & 47 & 39 & 39 \\
\hline
\end{tabular}


Table 4: The Effect of Foreign Aid on Economic Growth

(Controlling for Changes in Political Institutions)

\begin{tabular}{|c|c|c|c|c|c|c|}
\hline & \multicolumn{6}{|c|}{ Panel A: Dependent Variable is $\Delta \ln (\mathrm{y})$} \\
\hline & (1) & (2) & (3) & (4) & (5) & (6) \\
\hline & $\begin{array}{l}1960-2000 \\
\text { All LDCs }\end{array}$ & $\begin{array}{c}\text { 1960-2000 } \\
\text { Balanced Panel }\end{array}$ & $\begin{array}{c}1960-2000 \\
\text { Balanced Panel \& } \\
\text { Excluding Outliers }\end{array}$ & $\begin{array}{l}1970-2000 \\
\text { All LDCs }\end{array}$ & $\begin{array}{c}1970-2000 \\
\text { Balanced Panel }\end{array}$ & $\begin{array}{c}1970-2000 \\
\text { Balanced Panel \& } \\
\text { Excluding Outliers }\end{array}$ \\
\hline$\Delta \ln ($ aid $)$ & $\begin{array}{c}0.18 * * * \\
(4.64)\end{array}$ & $\begin{array}{c}0.25^{\text {*水水 }} \\
(4.14)\end{array}$ & $\begin{array}{c}0.24 \text { *水水 } \\
(5.57)\end{array}$ & $\begin{array}{c}0.16^{\text {**** }} \\
(4.31)\end{array}$ & $\begin{array}{c}0.22^{* * * *} \\
(3.37)\end{array}$ & $\begin{array}{c}0.22^{*} \text { *将水 } \\
(7.37)\end{array}$ \\
\hline$\Delta$ (polity2) & $\begin{array}{c}0.00 \\
(0.52)\end{array}$ & $\begin{array}{c}0.00 \\
(0.02)\end{array}$ & $\begin{array}{c}-0.01 \\
(-0.18)\end{array}$ & $\begin{array}{c}0.00 \\
(0.40)\end{array}$ & $\begin{array}{c}-0.00 \\
(-0.95)\end{array}$ & $\begin{array}{c}0.00 \\
(0.09)\end{array}$ \\
\hline First-Stage F-stat & 122.68 & 43.17 & 76.43 & 181.13 & 20.79 & 174.52 \\
\hline Country FE & Yes & Yes & Yes & Yes & Yes & Yes \\
\hline Year FE & Yes & Yes & Yes & Yes & Yes & Yes \\
\hline Observations & 1265 & 800 & 793 & 1093 & 984 & 972 \\
\hline \multirow[t]{4}{*}{ Countries } & 39 & 20 & 20 & 39 & 34 & 34 \\
\hline & \multicolumn{6}{|c|}{ Panel B: Dependent Variable is $\Delta \ln$ (aid) } \\
\hline & (1) & (2) & (3) & (4) & (5) & (6) \\
\hline & $\begin{array}{l}1960-2000 \\
\text { All LDCs }\end{array}$ & $\begin{array}{c}\text { 1960-2000 } \\
\text { Balanced Panel }\end{array}$ & $\begin{array}{c}1960-2000 \\
\text { Balanced Panel \& } \\
\text { Excluding Outliers }\end{array}$ & $\begin{array}{l}1970-2000 \\
\text { All LDCs }\end{array}$ & $\begin{array}{c}1970-2000 \\
\text { Balanced Panel }\end{array}$ & $\begin{array}{l}\text { 1970-2000 } \\
\text { Balanced Panel \& } \\
\text { Excluding Outliers }\end{array}$ \\
\hline$\Delta \ln (\mathrm{y})$ & $\begin{array}{c}-3.82 * * \\
(-2.34)\end{array}$ & $\begin{array}{c}-5.84 * * * \\
(-3.41)\end{array}$ & $\begin{array}{c}-6.29 * * * \\
(3.97)\end{array}$ & $\begin{array}{l}-2.88^{*} \\
(-1.80)\end{array}$ & $\begin{array}{c}-4.55 * * * \\
(-2.81)\end{array}$ & $\begin{array}{l}-5.34 * * \\
(-2.46)\end{array}$ \\
\hline$\Delta$ (polity2) & $\begin{array}{l}0.02 * * \\
(2.20)\end{array}$ & $\begin{array}{c}0.01 \\
(1.09)\end{array}$ & $\begin{array}{c}0.02 \\
(1.34)\end{array}$ & $\begin{array}{c}0.02 * * \\
(2.46)\end{array}$ & $\begin{array}{c}0.02 * * \\
(2.01)\end{array}$ & $\begin{array}{c}0.01 \\
(1.02)\end{array}$ \\
\hline First-Stage F-stat & 6.78 & 7.18 & 8.58 & 5.90 & 6.91 & 4.94 \\
\hline Country FE & Yes & Yes & Yes & Yes & Yes & Yes \\
\hline Year FE & Yes & Yes & Yes & Yes & Yes & Yes \\
\hline Observations & 1265 & 800 & 793 & 1093 & 984 & 972 \\
\hline Countries & 39 & 20 & 20 & 39 & 34 & 34 \\
\hline
\end{tabular}


Table 5: The Effect of Foreign Aid on Economic Growth

(Investment Response)

\begin{tabular}{|c|c|c|c|c|c|c|}
\hline \multicolumn{7}{|c|}{$\Delta \ln (i)$} \\
\hline & (1) & (2) & (3) & (4) & (5) & (6) \\
\hline & $\begin{array}{l}\text { 1960-2000 } \\
\text { All LDCs }\end{array}$ & $\begin{array}{c}1960-2000 \\
\text { Balanced Panel }\end{array}$ & $\begin{array}{c}1960-2000 \\
\text { Balanced Panel \& } \\
\text { Excluding Outliers }\end{array}$ & $\begin{array}{l}1970-2000 \\
\text { All LDCs }\end{array}$ & $\begin{array}{c}1970-2000 \\
\text { Balanced Panel }\end{array}$ & $\begin{array}{c}1970-2000 \\
\text { Balanced Panel \& } \\
\text { Excluding Outliers }\end{array}$ \\
\hline$\Delta \ln$ (aid) & $\begin{array}{l}0.14^{* * * *} \\
(2.70)\end{array}$ & $\begin{array}{c}0.30^{* * * * *} \\
(3.00)\end{array}$ & $\begin{array}{c}0.31^{* * * *} \text { * } \\
(2.70)\end{array}$ & $\begin{array}{l}0.15^{* *} \\
(2.30)\end{array}$ & $\begin{array}{l}0.17^{* * *} \\
(2.22)\end{array}$ & $\begin{array}{c}0.24^{* * * *} \\
(3.30)\end{array}$ \\
\hline First-Stage F-Statistic & 92.03 & 55.77 & 106.85 & 78.16 & 31.52 & 141.78 \\
\hline Country FE & Yes & Yes & Yes & Yes & Yes & Yes \\
\hline Year FE & Yes & Yes & Yes & Yes & Yes & Yes \\
\hline Observations & 1550 & 819 & 811 & 1341 & 1170 & 1150 \\
\hline Countries & 47 & 21 & 21 & 47 & 39 & 39 \\
\hline
\end{tabular}


Table 6: The Effect of Foreign Aid on Economic Growth (Using the Share of Aid in GDP and Controlling for Convergence Effects)

\begin{tabular}{|c|c|c|c|c|c|c|}
\hline \multicolumn{7}{|c|}{$\underline{\ln (\mathrm{y})}$} \\
\hline & (1) & (2) & (3) & (4) & (5) & (6) \\
\hline & $\begin{array}{l}1960-2000 \\
\text { All LDCs }\end{array}$ & $\begin{array}{c}1960-2000 \\
\text { Balanced Panel }\end{array}$ & $\begin{array}{c}1960-2000 \\
\text { Balanced Panel \& } \\
\text { Excluding Outliers }\end{array}$ & $\begin{array}{l}1970-2000 \\
\text { All LDCs }\end{array}$ & $\begin{array}{c}1970-2000 \\
\text { Balanced Panel }\end{array}$ & $\begin{array}{c}1970-2000 \\
\text { Balanced Panel \& } \\
\text { Excluding Outliers }\end{array}$ \\
\hline$\Delta \ln (\mathrm{aid} / \mathrm{y})$ & $\begin{array}{c}0.05 * * * \\
(3.25)\end{array}$ & $\begin{array}{c}0.07 * * * \\
(3.76)\end{array}$ & $\begin{array}{c}0.07 * * * \\
(3.10)\end{array}$ & $\begin{array}{c}0.06 * * * \\
(3.11)\end{array}$ & $\begin{array}{l}0.06 * * \\
(2.28)\end{array}$ & $\begin{array}{c}0.03 * * \\
(1.99)\end{array}$ \\
\hline L. $\ln (y)$ & $\begin{array}{c}-0.06 * * \\
(-1.98)\end{array}$ & $\begin{array}{c}-0.12 * * * \\
(-5.05)\end{array}$ & $\begin{array}{c}-0.10^{* * * *} \\
(-4.89)\end{array}$ & $\begin{array}{l}-0.06^{*} \\
(-1.87)\end{array}$ & $\begin{array}{c}-0.05 * * \\
(-2.24)\end{array}$ & $\begin{array}{l}-0.05 \\
(-1.20)\end{array}$ \\
\hline First-Stage F-Statistic & 49.19 & 25.75 & 47.84 & 37.64 & 15.34 & 63.99 \\
\hline Country FE & Yes & Yes & Yes & Yes & Yes & Yes \\
\hline Year FE & Yes & Yes & Yes & Yes & Yes & Yes \\
\hline Observations & 1550 & 819 & 811 & 1341 & 1170 & 1150 \\
\hline Countries & 47 & 21 & 21 & 47 & 39 & 39 \\
\hline
\end{tabular}


Table 7: The Effect of Foreign Aid on Economic Growth (Level Effects vs. Growth Effects)

\begin{tabular}{|c|c|c|c|c|c|}
\hline \multicolumn{6}{|c|}{$\Delta \ln (y)$} \\
\hline & (1) & (2) & (3) & (4) & (5) \\
\hline & $\begin{array}{l}1960-2000 \\
\text { All LDCs }\end{array}$ & $\begin{array}{l}1960-2000 \\
\text { All LDCs }\end{array}$ & $\begin{array}{l}1960-2000 \\
\text { All LDCs }\end{array}$ & $\begin{array}{l}1960-2000 \\
\text { All LDCs }\end{array}$ & $\begin{array}{l}1960-2000 \\
\text { All LDCs }\end{array}$ \\
\hline $\ln ($ aid) & $\begin{array}{l}0.01 \\
(1.32)\end{array}$ & $\begin{array}{c}-0.01 \\
(-0.87)\end{array}$ & $\begin{array}{r}-0.01 \\
(-1.45)\end{array}$ & $\begin{array}{c}-0.01 \\
(-1.03)\end{array}$ & $\begin{array}{c}-0.01 \\
(-1.04)\end{array}$ \\
\hline$\Delta \ln ($ aid) & $\underset{(3.49)}{0.11 \cdots * \cdot}$ & $\underset{(3.47)}{0.12 * \cdots}$ & $\begin{array}{c}0.14 \cdots \cdots \\
(3.03)\end{array}$ & $\underset{(2.92)}{0.17 * \cdots}$ & $\begin{array}{l}0.18 * \cdots \\
(3.03)\end{array}$ \\
\hline L. $\Delta \ln (y)$ & & $\begin{array}{c}0.83 * * * \\
(7.71)\end{array}$ & $\begin{array}{l}0.82 * 16 \\
(7.07)\end{array}$ & $\begin{array}{l}0.82 * * * \\
(5.44)\end{array}$ & $\begin{array}{l}0.79 * * * \\
(4.99)\end{array}$ \\
\hline L. $\Delta \ln$ (aid) & & & $\begin{array}{l}0.03 * * \\
(2.04)\end{array}$ & $\begin{array}{c}0.03 \\
(1.41)\end{array}$ & $\begin{array}{l}0.04 \\
(1.52)\end{array}$ \\
\hline L2. $\Delta \ln$ (aid) & & & & $\begin{array}{c}0.01 \\
(0.18)\end{array}$ & $\begin{array}{c}0.01 \\
(1.10)\end{array}$ \\
\hline L3. $\Delta \ln ($ aid) & & & & & $\begin{array}{c}0.01 \\
(1.31)\end{array}$ \\
\hline $\begin{array}{l}\text { Sum of Coefficients } \\
\text { on } \Delta \ln (\text { aid })\end{array}$ & & & $\begin{array}{l}0.17 * * * \\
(2.95)\end{array}$ & $\begin{array}{l}0.20^{* * * *} \\
(2.64)\end{array}$ & $\begin{array}{l}0.24^{* * * *} \\
(3.00)\end{array}$ \\
\hline First-Stage F-Statistic & 7.54 & 7.27 & 6.84 & 6.79 & 6.34 \\
\hline Country FE & Yes & Yes & Yes & Yes & Yes \\
\hline Year FE & Yes & Yes & Yes & Yes & Yes \\
\hline Observations & 1550 & 1497 & 1488 & 1440 & 1425 \\
\hline Countries & 47 & 47 & 47 & 47 & 47 \\
\hline
\end{tabular}


Appendix Table A1: Weak IV Estimators

\begin{tabular}{|c|c|c|c|c|c|c|}
\hline \multicolumn{7}{|c|}{$\underline{\ln (\text { aid })}$} \\
\hline & (1) & (2) & (3) & (4) & (5) & (6) \\
\hline & $\begin{array}{l}1960-2000 \\
\text { All LDCs }\end{array}$ & $\begin{array}{c}1960-2000 \\
\text { Balanced Panel }\end{array}$ & $\begin{array}{c}1960-2000 \\
\text { Balanced Panel \& } \\
\text { Excluding Outliers }\end{array}$ & $\begin{array}{l}1970-2000 \\
\text { All LDCs }\end{array}$ & $\begin{array}{c}1970-2000 \\
\text { Balanced Panel }\end{array}$ & $\begin{array}{c}1970-2000 \\
\text { Balanced Panel \& } \\
\text { Excluding Outliers }\end{array}$ \\
\hline $\begin{array}{l}\Delta \ln (\mathrm{y}) \\
\text { (Fuller 1) }\end{array}$ & $\begin{array}{c}-4.20^{\text {*** }} \\
(-2.20)\end{array}$ & $\begin{array}{c}-5.78^{* * * *} \\
(-3.46)\end{array}$ & $\begin{array}{c}-6.19 * * * * \\
(-4.25)\end{array}$ & $\begin{array}{l}-3.87^{* *} \\
(-2.00)\end{array}$ & $\begin{array}{c}-4.58 * * \\
(-2.61)\end{array}$ & $\begin{array}{c}-6.24^{* * * *} \\
(-2.65)\end{array}$ \\
\hline $\begin{array}{l}\Delta \ln (y) \\
\text { (Fuller 4) }\end{array}$ & $\begin{array}{c}-3.31 * * \\
(-2.31)\end{array}$ & $\begin{array}{c}-4.57^{* * * *} \\
(-4.12)\end{array}$ & $\begin{array}{c}-4.82^{* * * *} \\
(-4.31)\end{array}$ & $\begin{array}{c}-2.96^{* *} \\
(-2.15)\end{array}$ & $\begin{array}{c}-3.60 * * * \\
(-2.86)\end{array}$ & $\begin{array}{c}-4.63^{* * * *} \\
(-3.14)\end{array}$ \\
\hline $\begin{array}{l}\Delta \ln (\mathrm{y}) \\
(\mathrm{GMM} C \mathrm{CUE})\end{array}$ & $\begin{array}{c}-4.85^{* *} \\
(-2.35)\end{array}$ & $\begin{array}{c}-5.98^{* * * *} \\
(-5.02)\end{array}$ & $\begin{array}{c}-5.84^{* * * *} \\
(-5.48)\end{array}$ & $\begin{array}{c}-4.25^{* *} \\
(-2.03)\end{array}$ & $\begin{array}{c}-4.95^{* *} \\
(-2.52)\end{array}$ & $\begin{array}{c}-7.66^{* * * *} \\
(-3.19)\end{array}$ \\
\hline First-Stage F-Statistic & 9.32 & 7.76 & 10.03 & 8.14 & 10.08 & 8.18 \\
\hline Country FE & Yes & Yes & Yes & Yes & Yes & Yes \\
\hline Year FE & Yes & Yes & Yes & Yes & Yes & Yes \\
\hline Observations & 1550 & 819 & 811 & 1341 & 1170 & 1150 \\
\hline Countries & 47 & 21 & 21 & 47 & 39 & 39 \\
\hline
\end{tabular}


Appendix Table A2: Results Using Other Datasets

\begin{tabular}{|c|c|c|c|}
\hline \multicolumn{4}{|c|}{$\Delta \ln (y)$} \\
\hline & \multicolumn{3}{|c|}{ Panel A: IV-2SLS Estimates } \\
\hline & (1) & (2) & (3) \\
\hline Dataset From: & Burnside and Dollar (2000) & Easterly et al. (2004) & Roodman (2007) \\
\hline$\Delta \ln$ (aid) & $\begin{array}{c}0.19^{* * * *} \\
(3.88)\end{array}$ & $\begin{array}{c}0.10^{* * *} \\
(4.31)\end{array}$ & $\begin{array}{c}0.16^{* * *} \\
(3.04)\end{array}$ \\
\hline First-Stage F-stat & 77.71 & 227.72 & 58.96 \\
\hline Country FE & Yes & Yes & Yes \\
\hline Year FE & Yes & Yes & Yes \\
\hline Observations & 431 & 537 & 728 \\
\hline \multirow[t]{3}{*}{ Countries } & 94 & 111 & 124 \\
\hline & \multicolumn{3}{|c|}{ Panel B: LS Estimates } \\
\hline & (1) & (2) & (4) \\
\hline Dataset From: & Burnside and Dollar (2000) & Easterly et al. (2004) & Roodman (2007) \\
\hline$\Delta \ln$ (aid) & $\begin{array}{c}-0.04^{* *} \\
(-2.27)\end{array}$ & $\begin{array}{l}-0.03^{\text {t* }} \\
(-2.44)\end{array}$ & $\begin{array}{c}-0.05^{+* 4} \\
(-4.19)\end{array}$ \\
\hline Country FE & Yes & Yes & Yes \\
\hline Year FE & Yes & Yes & Yes \\
\hline Observations & 431 & 537 & 728 \\
\hline Countries & 94 & 111 & 124 \\
\hline
\end{tabular}


Figure 1. Distribution of Country-Specific Slope Estimates

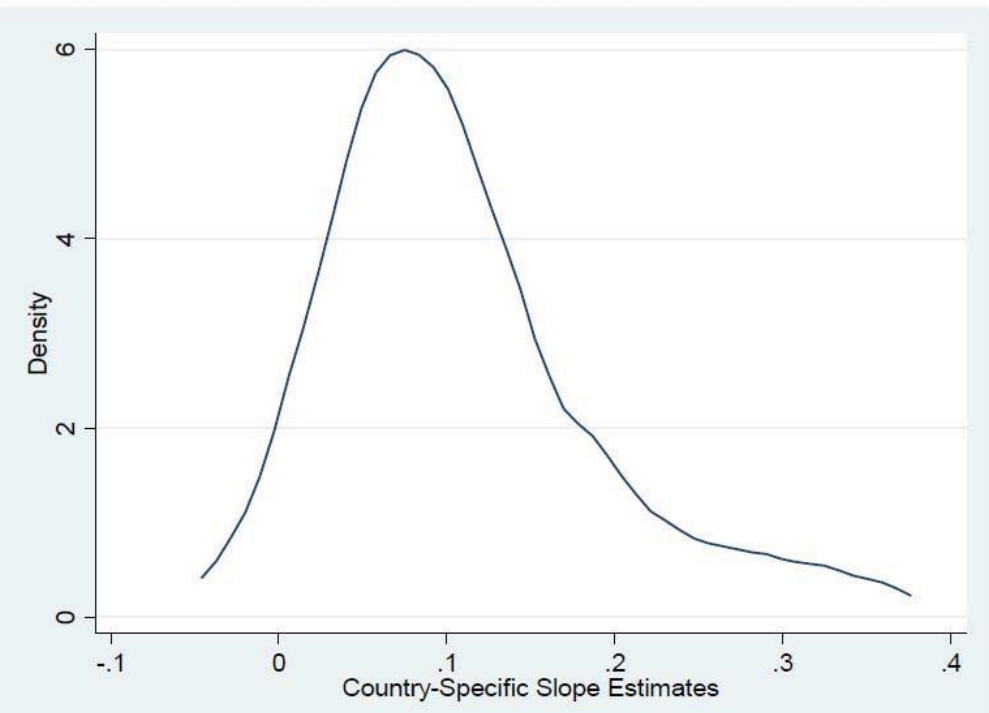

Note: The figure shows the density function of the country-specific slope estimates that are obtained by applying the Pesaran and Smith (1995) mean-group estimator and instrumenting the foreign aid series by the residual variation in foreign aid that is not driven by economic growth. The density function is estimated using an Epanechnikov kernel, with bandwidth selection based on Silverman's rule of thumb. 
Figure 2. The Role of Macroeconomic Policies

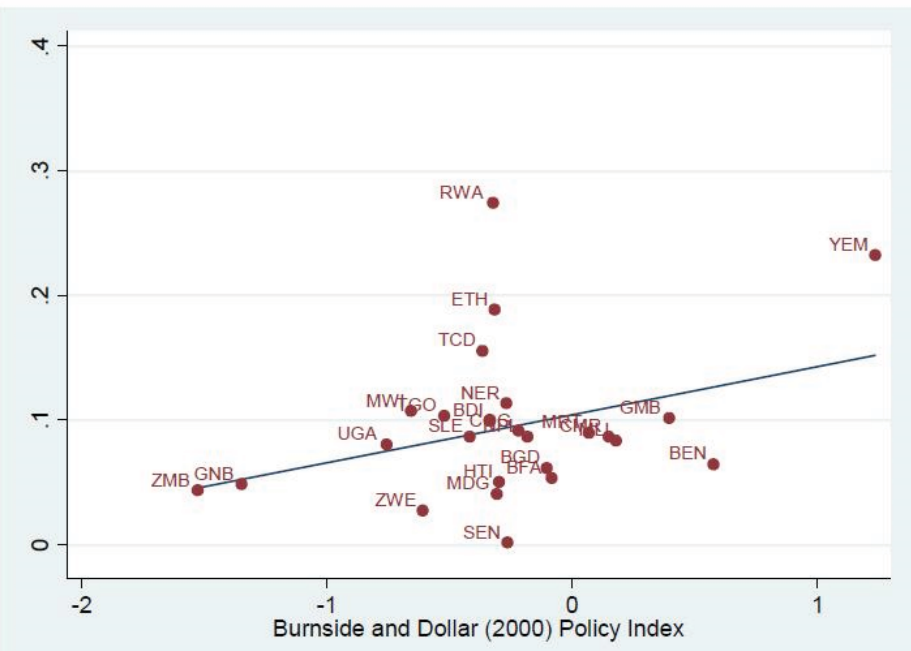

Note. The figure shows the relationship between the country-specific slope estimates (reported in Figure 1) and the Burnside and Dollar (2000) policy index. The bootstrapped slope coefficient (s.e.) of the fitted regression line is $0.04(0.02)$.

Figure 3. The Role of Tropical Terrain

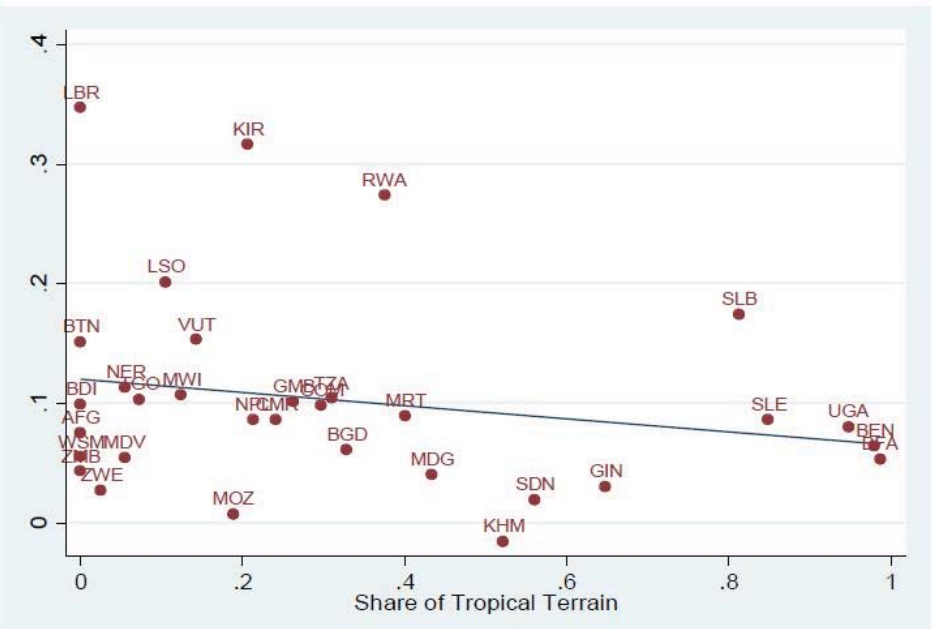

Note: The figure shows the relationship between the country-specific slope estimates (reported in Figure 1) and the share of tropical terrain. The bootstrapped slope coefficient (s.e.) of the fitted regression line is -0.05 (0.04). 
Figure 4. The Role of Financing Constraints

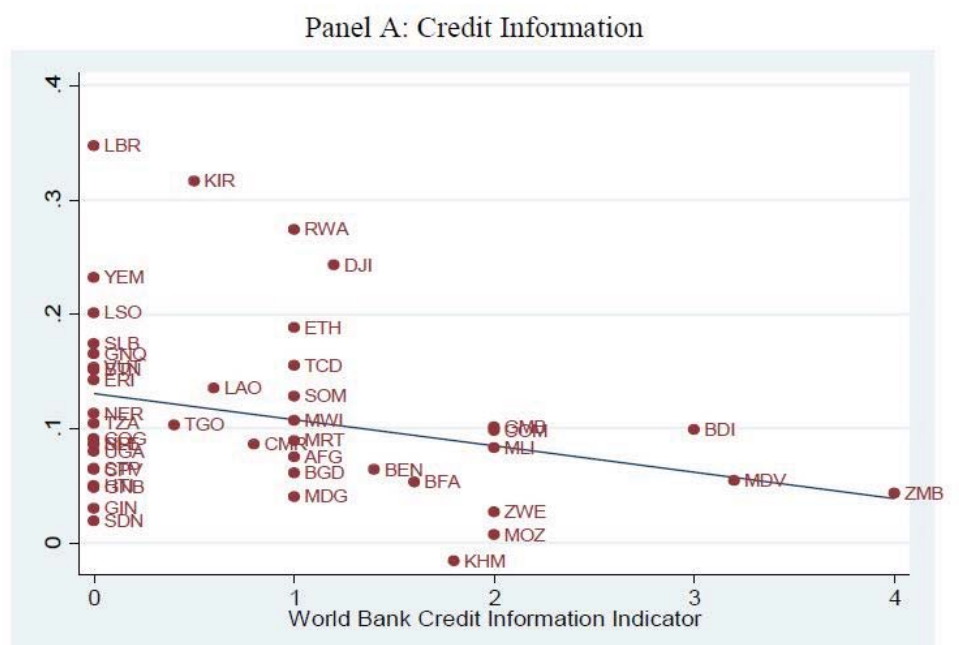

Note: The figure shows the relationship between the country-specific slope estimates (reported in Figure 1) and World Bank credit information indicator. Higher values of the credit information indicator represent better credit information. The bootstrapped slope coefficient (s.e.) of the fitted regression line is $-0.02(0.01)$.

Panel B: Credit Depth

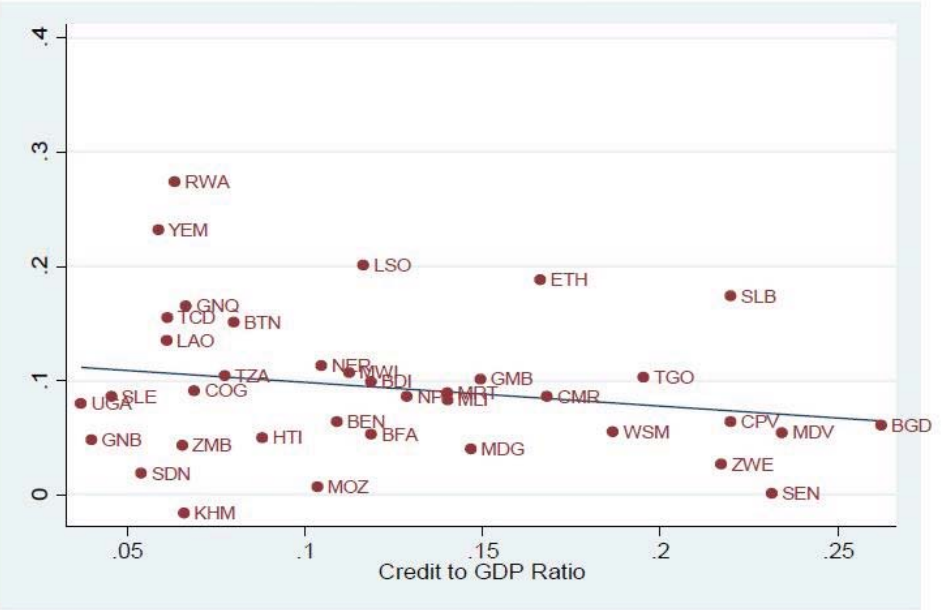

Note: The figure shows the relationship between the country-specific slope estimates (reported in Figure 1) and the ratio of public and private credit to GDP. The bootstrapped slope coefficient (s.e.) of the fitted regression line is $-0.21(0.16)$. 
Panel C: Percent of Population Living in Rural Areas

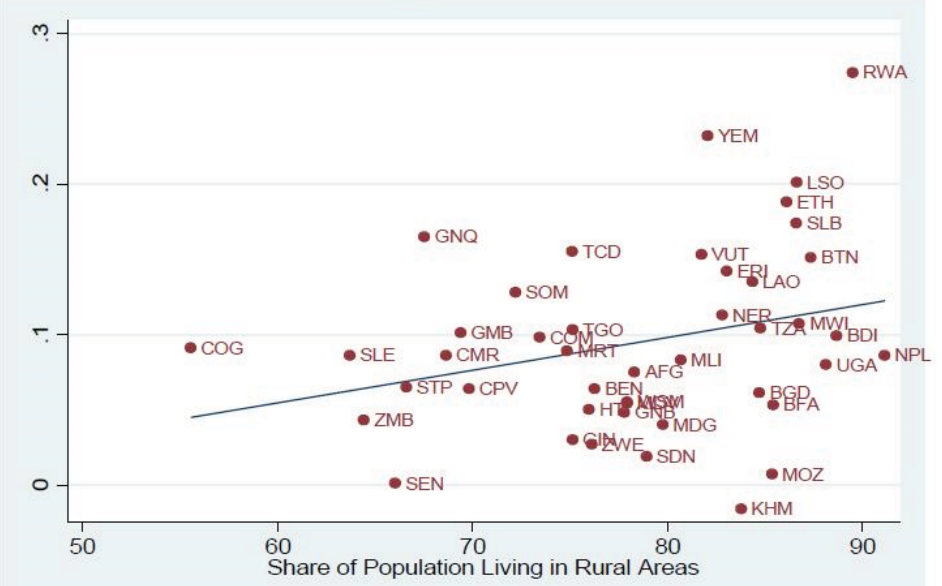

Note: The figure shows the relationship between the country-specific slope estimates (reported in Figure 1) and the percentage share of the population living in rural regions. The bootstrapped slope coefficient (s.e.) of the fitted regression line is $0.002(0.001)$. 
Figure 5: The Role of Ethnic Divisions

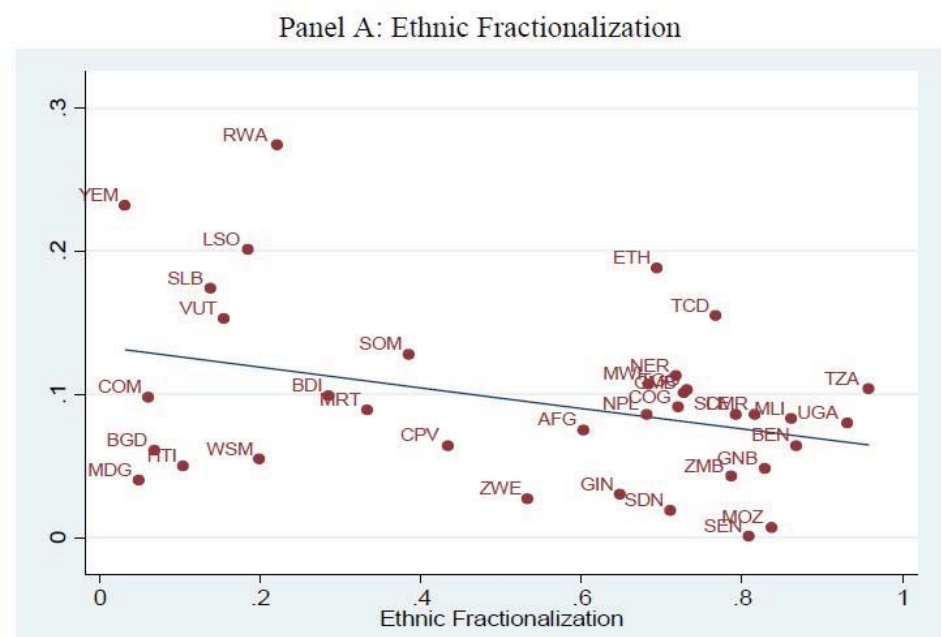

Note: The figure shows the relationship between the country-specific slope estimates (reported in Figure 1) and ethnic fractionalization. The bootstrapped slope coefficient (s.e.) of the fitted regression line is $-0.07(0.03)$.

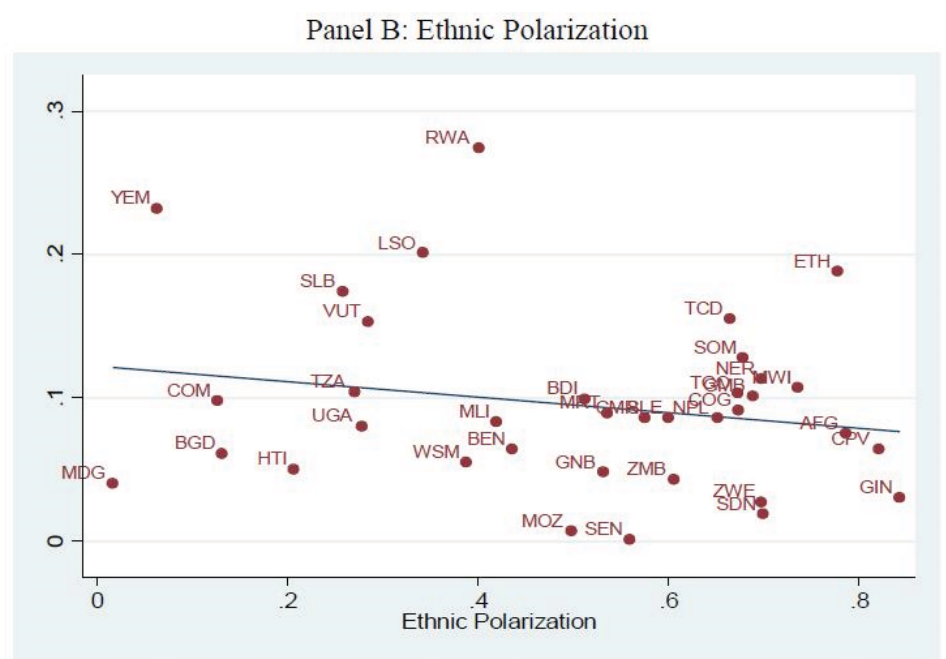

Note: The figure shows the relationship between the country-specific slope estimates (reported in Figure 1) and ethnic polarization. The bootstrapped slope coefficient (s.e.) of the fitted regression line is $-0.05(0.05)$. 